\title{
Epilogue: Pan Narrans
}

Now twenty years ago,

This day we found the thing;

With science and with skill

We found; then came the sting-

What we with endless labour won

The thick world scorned;

Not worth a word to-day-

Not worth remembering. ${ }^{1}$

-From 'The Anniversary (20th August 1917)'

As I opened with a poem, it seems appropriate that I close with one. Written in 1917, 20 years after his discovery, 'The Anniversary' voices Ross's dismay at the lukewarm response to his work. Whilst many congratulated him on his 'ground-breaking' intellectual discovery, the practical implementations of sanitary measures for mosquito control were subject to unilateral and intermittent adoption by local governments. As Christian Strother has noted, the 'inherent localism in health policy in the late nineteenth and early twentieth century allowed for a variety of responses to contemporary scientific research on malaria'. ${ }^{2}$ Ross advised

${ }^{1}$ Quoted in Malcolm Watson, 'Ronald Ross, 1857-1932' Science Progress in the Twentieth Century (1919-1933) 27.107 (January 1933) 377-92 (p. 386).

${ }^{2}$ Christian Strother, 'Waging War on Mosquitoes: Scientific Research and the Formation of Mosquito Brigades in French West Africa, 1899-1920' Journal of the History of Medicine

(C) The Author(s) 2022

E. Taylor-Pirie, Empire Under the Microscope, Palgrave Studies in

Literature, Science and Medicine, https://doi.org/10.1007/978-3-030-84717-3_7 
setting up 'mosquito brigades' to exterminate mosquito larvae and eliminate breeding grounds; however, the system was rejected wholesale or after only a short trial in many places. The brigades introduced by Ross to Freetown, Sierra Leone, in 1899, for example, were quickly abandoned once the Liverpool School of Tropical Medicine ceased directly supervising them. ${ }^{3}$ Conversely, the Government of French West Africa was inspired by the Freetown system to adopt their own brigades, which had lasting success in reducing rates of malaria in the region. Whilst mosquito brigades were implemented at Khartoum, Zanzibar, and the Federated Malay States, they were rejected by 12 district boards and 39 municipal councils in the Madras Presidency in India owing to resistance from local health officials and concerns about cost. Despite success in the Federated Malay States, at Panama, in the Gambia, French West Africa, and in Sumatra, Ross insisted that the world did not listen and his 'endless labour' was in vain.

In 1933, parasitologist Malcolm Watson (1873-1955) wrote an obituary of Ross in which he also lamented the unilateral adoption of antimalaria sanitation measures and reprinted several of Ross's poems. In 1900, having studied medicine and arts at the University of Glasgow, and with a diploma in Public Health from Cambridge, Watson joined the Malayan Medical Service. He received his MD in 1903 with a thesis entitled 'The Effect of Drainage on Malaria' and became a pioneer of malaria prevention. Whilst in British Malaya he carried out his own research into 'species sanitation' - the idea that vector control measures must be adapted to the individual species of mosquito and their terrain. A lifelong friend of Ross, he went on to join the Ross Institute as Principal of the Department of Malaria Control in 1928. Ross later argued that Watson's work in British Malaya was 'the greatest sanitary achievement ever accomplished in the British Empire'.

Watson's obituary brings Ross's professional self-fashioning full circle. Commenting on Ross's visit to Singapore in 1926, he writes,

His sojourn in Malaya was balm to the bruises and wounds of this old fighter [...] How he felt about it may be learned from his inscription in a copy of Poems, which he gave me [...] "Sir Malcolm Watson, who proved the piece on page 77 was a damned lie. Ronald Ross, 10th August 1928." On turning

and Allied Sciences 71.4 (October 2016) 447-68 (p. 447).

${ }^{3}$ Strother, 'Waging War on Mosquitoes', p. 450. 
to page 77 I found "The Anniversary, 20th August 1917" [...] the sting had been drawn. At long last he felt he could put off his armour. ${ }^{4}$

His comments offer the narrative resolution that Ross so craved during his lifetime, cementing the story of Ross's discovery as a legendary labour using the mode of heroic biography. Whilst historiographies of medicine no longer subscribe to the idea that science is a 'quest' undertaken by great men (and occasionally great women), the mode has exerted a lasting influence on popular understandings of the role of medicine in society. Many scientists at the fin de siècle were also historians of their discipline, producing amalgams of fact and fiction that have demonstrated incredible endurance. Doctors and scientists still routinely cite books like Paul de Kruif's sensational popular history Microbe Hunters (1926) as inspiration for their decisions to enter the medical profession. In 2014, for instance, Anthony Cerami, clinical pathologist and chief executive officer at Araim Pharmaceuticals, recalled: 'as a child, I, like many scientists of my age, had read Microbe Hunters by Paul de Kruif' ${ }^{5}$ Cerami was clearly influenced by the narrative style of books like Microbe Hunters as well as their content, describing his own work on diabetes and cachexia-uncritically and on more than one occasion-as a 40-year 'Odyssey' (400; 407). In 2012, biochemist and then editor of Current Science, Padmanabhan Balaram also singled out de Kruif's book, noting that 'generations of researchers grew up reading Paul de Kruif's 1926 classic, Microbe Hunters, which remains a compellingly romantic account of the golden age of bacteriology and microbiology'. ${ }^{6}$ Balaram asks: 'should a book on science written in 1926 be recommended nearly ninety years later?' Yes is the short answer. De Kruif's narrative style is 'part of the magic' which has drawn student readers to the practice of science, he argues.

Lilian R. Furst argues that the emotional power of popular histories of science is often attributable to the 'adoption of narrative strategies characteristic of creative writing rather than the chronicle mode of history'? These not-quite novelised histories contain fictive and non-fictive knowledge, 'exuberant rhetoric', a 'pictorial technique', 'reader-oriented' prose,

${ }^{4}$ Watson, p. 390.

${ }^{5}$ Anthony Cerami, 'A Forty-Year Odyssey in the Sea of Translational Medicine' Proceedings of the American Philosophical Society 158.4 (December 2014) 400-10 (p. 404).

${ }^{6}$ P. Balaram, 'Men and Microbes: War and Peace' Current Science 103.2 (25 July 2012) $123-24$ (p. 123).

${ }^{7}$ Lilian R. Furst, 'Fictionalizing Fact' The Comparatist, 21 (May 1997) 4-9 (p. 5). 
and a biographical method that evokes the 'excitement, triumphs, and tensions of medical research' (7). She contrasts both Microbe Hunters and Sherwin B. Nuland's Doctors: The Biography of Medicine (1988), both written by doctors, with Edwin H. Ackerknecht's dry and 'deadly to read' A Short History of Medicine (1955, rev. 1982). She dubs Ackerknecht's 'encyclopaedic' text an 'undifferentiated catalogue of names, dates, and discoveries' (6), which offers no historical context and lacks awareness of his readers.

Clearly Ackerknecht's text is not a good model for popular history, but what of de Kruif's? Or, indeed, Ross's? In striving to offer something more than a 'record of results', Ross's Memoirs encapsulates the difficulty in not only communicating science to a lay audience but of making it meaningful in relation to existing knowledge. It highlights the fraught imaginative processes and literary-linguistic practices that are intrinsic to the production and reporting of science. After all, fiction is not the opposite of truth. As Furst asserts 'all historical images partake of the fictional insofar as narrative history, far from being a dispassionate chronicle of stable occurrences in the past, is a reconstructive and interpretative act filtered through the historian's perspective' ${ }^{8}$ This makes fact and fiction 'not only coextensive, but porous' (4).

And so our understandings of science in the past-and in the presentare necessarily hybrids of fact and fiction that tell us something interesting about the moments that produced them. As George Lakoff and Mark Johnson famously explored in Metaphors We Live By (1980), linguistic and conceptual structures like metaphor and narrative give coherence to our everyday thoughts, feelings, and actions. ${ }^{9}$ For James Geary, metaphorical thinking - understanding one thing in terms of another (like parasitology research in terms of Arthurian quest) - 'shapes our view of the world, and is essential to how we communicate, learn, discover, and invent'. ${ }^{10}$ In his Discworld franchise, Terry Pratchett goes as far as to conceptualise the narrative imperative that directs our lives as a physical substance, an element called narrativium that literally forms his fictional universe. He argues that rather than Homo sapiens, we might more appropriately be named

${ }^{8}$ Lilian R. Furst, 'Fictionalizing Fact' The Comparatist, 21 (May 1997) pp. 4-9.

${ }^{9}$ See: George Lakoff and Mark Johnson, Metaphors We Live By (Chicago: University of Chicago Press, 1980).

${ }^{10}$ James Geary, I Is an Other: The Secret Life of Metaphor and How It Shapes the Way We See the World (New York: HarperCollins, 2011) p. 3. 
Pan narrans: the story-telling ape. ${ }^{11}$ It is crucial, then, that we reflect critically on the stories we tell.

Empire Under the Microscope has examined how poetic, literary, historical, and scientific knowledge united to shape a fledging discipline as it attempted to locate itself in relation to British imperial identity. It demonstrates how an interdisciplinary approach to the history of parasitology deepens our understanding of the cultural investments of scientific practice and reveals the multiform entanglements between science and empire at the turn of the century. Contextual histories that take into account the diverse influences of people, institutions, objects, ideas, material conditions, and textual productions encourage us to reflect critically on how knowledge is produced and valued. Such histories also enable us to identify and interrogate legacies that have become naturalised in ways that are harmful. Ross's professional self-fashioning might originally have been part of an attempt to garner funding and support but those same narratological manoeuvres now often obscure the realities and hardships of medical work.

In 2020, a global pandemic - still ongoing at the time of writing-radically changed the daily lives of millions. In the United Kingdom, political and media narratives focused our attention on the pivotal role of healthcare workers in times of national emergency using a lexis of heroism and self-sacrifice. Annemarie Plas, a Dutch national living in London, started a weekly 'Clap for Our Carers' (later rebranded 'Clap for Our Heroes') as a show of national solidarity. The impressive grassroots campaign became a national movement championed by politicians, celebrities, and chief executives of the National Health Service (NHS). It reached new visibility after Prime Minister Boris Johnson contracted, was hospitalised, and then recovered from Covid-19. He subsequently capitalised on the national weekly tradition of applauding the NHS and doubled down on the heroism rhetoric. Although the original campaign was well intentioned and echoed public applause for healthcare workers world-wide, it soon became clear that the endless clapping and praise for our 'healthcare heroes' by politicians were not acts of genuine appreciation, but tedious performative gestures. As palliative care doctor Rachel Clarke wrote:

${ }^{11}$ Terry Pratchett, Ian Stewart, and Jack Cohen, The Science of Discworld II: The Globe (London: Ebury Press, 2002) p. 325. 
[A]ll those public declarations of praise-so fervently tweeted, televised, promoted and shared-have the advantage of being entirely free. They cost the politician, and the Treasury, nothing at all. ${ }^{12}$

By mobilising a narrative of NHS heroism, politicians sought to divert attention from the announcement of an insulting $1 \%$ pay raise for nurses (a mere $£ 3.50$ a week for experienced nurses, and less for those earlier in their career). Heroes, after all, are supposed to perform self-sacrificing deeds. As Rachel Davies points out 'it's vital we remember that our frontline workers $[\ldots]$ are real people struggling just as much as the rest of us'. Videos of burnt-out healthcare staff, exhausted, demoralised, and struggling with inadequate personal protective equipment (PPE) subsequently flooded social media. They appealed not for applause, but for decent wages, adequate PPE, and employee protections. The heroism discourse deflects accountability and 'by clapping and cheering on Thursdays, we are complicit', Davies argues. ${ }^{13}$

The medico-military metaphor does kindred political work and its legacy is overt in coronavirus briefings in which Johnson dubbed Covid-19 'the biggest threat this country has faced for decades', an 'invisible killer' that we must 'fight' together. Supermarket staff, transport workers, carers, nurses, and doctors are all 'on the frontline. But in this fight, we can be in no doubt that each and every one of us is directly enlisted', he asserted. ${ }^{14}$ Throughout the pandemic, he has consistently employed these semantics to instil a sense of national responsibility using the 'Blitz spirit' narrative that 'we are all in this together', a mentality that occludes the fact that healthcare outcomes for Black, Asian, and minority ethnic communities are considerably poorer than for Caucasians. 'We must carry on waging this long, hard fight against Coronavirus', Johnson insisted, using recurring phrases like 'holding our nerve' and 'fighting the enemy'. The 'great

\footnotetext{
${ }^{12}$ Rachel Clarke, 'Now We Healthcare Workers Know Exactly How Empty Boris Johnson's “Clap for Heroes" Really Was' The Guardian Friday 5 March 2021 https://www.theguardian.com/commentisfree/2021/mar/05/boris-johnson-clap-patients-pay-offer [accessed 5 April 2021].

${ }^{13}$ Rachel Davies, 'Don't Clap for Our Carers_Give Them a Pay Rise' Huffpost, 7 January 2021 https://www.huffingtonpost.co.uk/entry/clap-for-our-heroes_uk_5ff7lf2ac5b61 a92a8c06cle [accessed 5 April 2021].

${ }^{14}$ Boris Johnson, 'Prime Minister's Statement on Coronavirus (COVID-19): 23 March 2020' https://www.gov.uk/government/speeches/pm-address-to-the-nation-on-corona virus-23-march-2020 [accessed 5 April 2021].
} 
British people' will 'carry us through and see us to victory over this virus'. ${ }^{15}$ Here the military metaphors deflect accountability from government response, placing emphasis instead on a public who must 'play their part' (another recurring phrase) to defeat the enemy.

Speaking of the rush to develop a vaccine Johnson waxed lyrical:

We have talked for a long time, or I have, about the distant bugle of the scientific cavalry coming over the brow of the hill. And tonight that toot of the bugle is louder. ${ }^{16}$

And on another occasion: "we can hear the drumming hooves of the cavalry coming over the brow of the hill' ${ }^{17}$ Like Ross, he employs an imperialistic and romanticised version of military encounter, more invocative of Tennyson's poetic narrative in 'The Charge of the Light Brigade' (1854) than the realities of modern military warfare (notwithstanding the fact that the charge failed). He subsequently highlighted the material intersections that prop up such analogies by announcing:

I will now hand over to Brigadier Fossey to talk about the unrivalled logistical expertise of the British army that's helping to deliver mass testing to Liverpool. ${ }^{18}$

Health secretary, Matt Hancock, similarly reminded listeners of these intersections, declaring,

[T] he army is working hand in glove with the NHS and local councils to set up our vaccine network using battle preparation techniques to help us keep up the pace.

${ }^{15}$ Boris Johnson, 'Prime Minister's Statement on Coronavirus (COVID-19): 23 June 2020'https://www.gov.uk/government/speeches/prime-ministers-statement-to-the-houseon-covid-19-23-june-2020 [accessed 5 April 2021].

${ }^{16}$ Boris Johnson, 'Prime Minister's Statement on Coronavirus (COVID-19): 9 November 2020' https://www.gov.uk/government/speeches/prime-ministers-statement-on-corona virus-covid-19-9-november-2020 [accessed 5 April 2021].

${ }^{17}$ Boris Johnson, 'Prime Minister's Statement on Coronavirus (COVID-19): 23 November 2020' https://www.gov.uk/government/speeches/prime-ministers-statement-on-corona virus-covid-19-23-november-2020 [accessed 5 April 2021].

${ }^{18}$ Johnson, 'Prime Minister's Statement on Coronavirus (COVID-19): 9 November 2020'. 
As the vaccination programme was rolled out, Hancock insisted that it was 'one of the biggest logistical exercises since the war'. ${ }^{19}$ Hancock's vague reference to 'the war' (rather than the Second World War or any of the upwards of 30 wars that the United Kingdom has engaged in since then) plays on a national aesthetic of Blitz tearooms, ration books, union jacks, and solidarity. Such images risk encouraging vaccine nationalism, exemplified by a coronavirus briefing in which a Times Radio journalist asked director of the Oxford vaccine group Professor Andrew Pollard:

Without wanting you to blow your own trumpet because you're British and Oxford is British —although if you'd like to I think everyone would like that as well—can you say how much better is your vaccine [than] Pfizer's [...] is it just a better vaccine? ${ }^{20}$

Pollard's answer-that it was 'not a competition', but a global problem with a global solution-was admirably balanced; nevertheless, the conversation points to a fusing of British science and British nationhood that has a long history, as this book attests, and one which was shaped by the imperial imagination.

Empire Under the Microscope brings into focus some of the ways in which imperial fervour, literary forms, and knowledge about tropical illness collided at the turn of the century to provide a toolkit for speaking about medicine and nationhood that remains with us. Archetypes like the chivalrous knight, the intrepid explorer, the soldier hero, and the discerning detective became political short-hands for conceptualising the professional identities, social value, and scientific methodologies of parasitologists. Proponents of this new science of empire made use of forms like maps and biographies, and modes like adventure and romance to help narrate and formulate their work. Another prominent and recurring narratological strategy was that of medicine as war, a trope that infiltrated fiction and nonfiction alike and that has left a heavy legacy in discourses of public health. In Voices Prophesying War, I. F. Clarke outlines the primacy of war

${ }^{19}$ Matt Hancock, 'Health and Social Care Secretary's statement on coronavirus (COVID-19): 17 March 2021' https://www.gov.uk/government/speeches/health-andsocial-care-secretarys-statement-on-coronavirus-covid-19-17-march-2021 [accessed 5 April 2021].

20 'Coronavirus press conference (23 November 2020)' YouTube https://www.youtube. com/watch?v=zT_VQEp3I_8 [accessed 5 April 2021]. 
in the literary imagination in the period $1871-1914 .{ }^{21} \mathrm{He}$ argues that advances in science and technology provided the kindling for myriad stories of imagined warfare, maintained by political anxieties regarding the security of Britain as a European power. It is thus unsurprising that parasitologists employed the popular motif of war to understand the relationship between man and nature in the context of imperial precarity. Clarke argues that imaginary wars in the 1890 s were 'burdened by a long tradition, which presented war as an affair of brief battles and heroic deeds by individuals', a tradition to which it is clear that parasitologists also subscribed. ${ }^{22}$ This is evident in Ross's formulation of vector control and sanitation measures in his 1901 book Mosquito Brigades, which was advertised as 'an authoritative work by a World Famous Scientist Indispensable to All Engaged in the Warfare Against the Deadly Mosquito'. ${ }^{23}$ 'Brigade' here suggests an alignment with Clarke's notion of war as predicated on heroic battles and military sub-units.

As I explored in my first chapter, the parasitology narrative put forth by its proponents often favoured an even older kind of warfare: that of the chivalric knight, in a fervent adherence to myths of historical nationhood. In reimagining British imperial identity as part of their professional selffashioning, proponents combined the iconography of stories like St George and the dragon with the epic poetics of Greco-Roman mythology, providing a bridge for imagining themselves as part of a historic tradition of heroism that was specific to Britain but global in nature. Their narrative strategies were influenced by the medieval revival, Carlylean heroism, and the rise of the adventure genre, which they in turn inspired. As Norman Vance has argued, the literary cultures from which individuals would draw models for imperial masculine citizenship were dominated by the concept of 'Christian manliness'. A book of the same name published in 1867 by Revd S. S. Pugh - which drew on material from the Bible alongside military heroes associated with the Indian Rebellion and abolition of the slave trade-illustrates a collision of religious dogma, physical prowess, and moral virtue that would come to characterise the 'muscular Christianity'

\footnotetext{
${ }^{21}$ Although the book addresses the wider time period of 1763-1984, Clarke identifies this specific time period in chapter one as a significant epoch of thought marked by the publication of George Chesney's The Battle of Dorking at the one end and the beginning of the First World War at the other.

${ }^{22}$ I. F. Clarke, Voices Prophesying War, 1763-1984 (London: Oxford University Press, 1966) p. 69.

${ }^{23}$ London, LSHTM. RC. Ross/64/02. Pamphlet to advertise 'Mosquito Brigades'.
} 
of imperialism-and, I argue, of parasitology. ${ }^{24}$ In many ways, Vance asserts, the Victorian period was characterised by Elizabeth Barrett Browning's moralistic comment in Aurora Leigh (1856) that 'all men [are] possible heroes':

And all men possible heroes: every age,

Heroic in proportions, double-faced,

Looks backward and before, expects a morn

And claims an epos. (5.139-54)

The tensions inherent in expecting a morn and claiming an epos are writ large in histories of parasitology at the turn of the century wherein figures like Ross reach back to the imagined heroism of the past to construct heroism in the present-insisting on their fitness for Homeric record but also lamenting the unglamorous and small-minded realities of imperial administration.

Proponents located parasitology within this tradition by emphasising, not the full complexities of modern clinical and laboratory research, but a polarising stand-off between 'anti-imperial malaria' and the scientific discoverer, whose work would secure 'the prosperous and progressive future of the British Empire'. ${ }^{25}$ Ross's work, for example, was often heralded as a form of imperial expansion:

Mr. Ure, when Lord Advocate, was fond of saying up and down the country that nobody could add an acre to the land originally given to us by the Creator. As a saleable and inhabitable commodity, I wonder how many acres Sir Ronald's discoveries have added to the map of the empire? ${ }^{26}$

The work of parasitologists varied widely and included collecting specimens as part of fieldwork; dissecting and analysing samples in the laboratory; diagnosing, and in some cases experimenting on, patients; looking through microscopes, taking down temperatures, drawing up graphs, or writing papers for the medical press, and-later-carrying out sanitation work. Practitioners might be based in India, Africa, America, Asia, Italy,

\footnotetext{
${ }^{24}$ Norman Vance, The Sinews of the Spirit: The Ideal of Christian Manliness in Victorian Literature and Religious Thought (Cambridge: Cambridge University Press, 1985) p. 1.

25 'Empire Leading Article-Imperial Bacteriology' Financial Times, 23 January 1913, n.p.

${ }^{26}$ Henry Faulds, 'The Reward of Research' British Medical Journal, 1.2781 (18 April 1914) p. 888.
} 
China, the Philippines, or even at the Albert Dock Seamen's Hospital in London. However, the overwhelmingly prevalent representation of the parasitologist was out in the 'wilds' of Africa and up against a personal and deadly threat. At a reception held to celebrate Ross's Nobel Prize, for instance, $\mathrm{Mr} \mathrm{C}$. W. Jones announced that they were 'there that night to do honours and justice to a hero from Africa who had been occupied in a war, not against his fellow men, but against a most insidious enemy to mankind in general'. ${ }^{27}$

This war was a war of sanitation, Ross having lately been in West Africa with the Liverpool School of Tropical Medicine studying mosquito species and their breeding grounds in Freetown, Sierra Leone. Ross went out to Africa with Dr Henry E. Annett (demonstrator at the Liverpool School) and Ernest E. Austen (curator of entomology at the British Museum). And upon finding a species of Anopheles mosquito that transmits malaria, they were joined by Dr Robert Fielding-Ould of the Royal Army Medical Corps. Nevertheless, press coverage exaggerated the dangerousness of the trip and made little mention of Ross's companions, as in this newspaper report from 1912, which asserted:

[Ross's] research took him into the deadliest districts of West Africa, where for months he risked his life, every hour, night and day, for the cause of medical science and humanity. ${ }^{28}$

It is just such narratives of self-sacrifice and altruism that blind us to racism inherent in empire; in reality, as benefactor Alfred Lewis Jones asserted, they were not just forwarding medical science and defending humanity but 'fighting the battle of commerce' - if the men of the future [are] to have a chance of fighting the battle of commerce, they must be better trained in science'.$^{29}$

Whilst parasitologists were framed as imperial heroes in legendary battles, their subjects of study were reconceptualised as enemies, criminals, and monsters to be cleansed from imperial space. The anthropocentric semantics of war, violence, and criminality characterised tropical illness as another form of colonial insurrection with medical and sanitary intervention as an extension of the disciplinary law-and-order state. This, in turn,

27 'Liverpool' British Medical Journal 1.2192 (3 January 1903) p. 48.

28 'Martyrs to Science. Medical Men's Toll of Life' Cape Argus, 14 December 1912, n.p.

29 'Liverpool' British Medical Journal 1.2196 (31 January 1903) pp. 285-86 (p. 285). 
worried the boundaries between microbial and imperial 'colonies', which were frequently analogised. Such examinations add important context to the power and reach of imperial fantasies, as well as illuminating the analogies that we use to navigate healthcare and global politics. Whilst the language of medicine as war has become naturalised, so has the idea of doctors as detectives and of health workers as heroes. In this book, I seek to demonstrate how stories of science and stories of empire shaped each other in ways that are contingent on this historical moment but that continue to inflect and occlude our self-knowledge. By placing empire under the microscope, we bring into focus complex medical, political, material, and imaginative contexts that continue to inform our attitudes to science, our conceptualisations of disease, and our relationships to global others.

Open Access This chapter is licensed under the terms of the Creative Commons Attribution 4.0 International License (http://creativecommons.org/licenses/ by $/ 4.0 /$ ), which permits use, sharing, adaptation, distribution and reproduction in any medium or format, as long as you give appropriate credit to the original author(s) and the source, provide a link to the Creative Commons licence and indicate if changes were made.

The images or other third party material in this chapter are included in the chapter's Creative Commons licence, unless indicated otherwise in a credit line to the material. If material is not included in the chapter's Creative Commons licence and your intended use is not permitted by statutory regulation or exceeds the permitted use, you will need to obtain permission directly from the copyright holder. 